\title{
CORTICOSTEROID RELEASE AND SYNTHESIS IN VITRO BY ADRENAL SLICES FROM PATIENTS WITH CUSHING'S SYNDROME*
}

\author{
By PATRICK J. MULROW AND GEORGE L. COHN $\dagger$
}

(From the Medical Service, Veterans Administration Hospital, West Haven, and the Department of Medicine, Yale University School of Medicine, New Haven, Conn.)

(Submitted for publication February 10, 1961 ; accepted March 23, 1961)

Histological methods cannot accurately assess the functional capacity of the human adrenal cortex. About 36 per cent of patients with Cushing's syndrome are reported to have adrenal glands normal in weight and histological appearance $(1,2)$. Adrenal adenomas are considered functional only if they are associated with atrophy of nonadenomatous adrenal tissue. Moreover, certain tumors of the adrenal medulla and kidney cannot be distinguished from cortical neoplasms by histological techniques (3).

Several recent reports have demonstrated that the human adrenal cortex retains much of its activity in vitro (4-11). Adrenal homogenates or slices have been found to produce steroids, incorporate precursors into more complex compounds, and respond to ACTH. ${ }^{1}$ Cooper and co-workers showed that adrenal slices produced the same corticosteroids in vitro that were found in adrenal vein blood (8). Bongiovanni (9) demonstrated that homogenates of adrenals from patients with congenital adrenocortical hyperplasia were unable to hydroxylate the 21 -carbon atom of steroid precursors, a defect present in vivo. Incubation experiments with rat, ox, and human adrenal slices indicate that the steroids are readily released into the incubation media (10-14); this technique therefore affords the opportunity to investigate directly the function and biosynthesis of steroids by human adrenal tissue.

* This work was supported by Grants C-3998 and A-254 (C8) from the US Public Health Service.

$\dagger$ Advanced Research Fellow of the American Heart Association during part of this study.

${ }^{1}$ Compounds referred to are: ACTH, adrenocorticotropic hormone. Compound . F, cortisol (11 $\beta, 17 \alpha, 21$-trihydroxy-4-pregnene-3,20-dione). Compound $\mathrm{E}$, cortisone (17 $\alpha, 21$-dihydroxy-4-pregnene-3,11,20-trione). Compound $\mathrm{B}$, corticosterone (11 $\beta, 21$-dihydroxy-4-pregnene3,20-dione). Compound S, 11-deoxycortisol (17 $\alpha, 21$-dihydroxy-4-pregnene-3,20-dione). Aldo, aldosterone (11 $\beta$, 21-dihydroxy-18-aldo-4-pregnene-3,20-dione).
The present report is a study of the corticosteroids synthesized and released into the media after incubation of atrophic, "normal," hyperplastic, and adenomatous adrenal tissue slices from two patients with hypertension and four with Cushing's syndrome.

\section{SUBJECTS AND METHODS}

Seven adrenals and three adenomas were removed from 4 patients with Cushing's syndrome and two adrenals from a patient with malignant hypertension. In a patient who underwent a laparotomy for a suspected pheochromocytoma, the right adrenal was removed because of a small mass in one pole which was found to be a hemorrhage of recent origin and not a pheochromocytoma; otherwise, the gland was of normal weight and histological appearance. An adenoma and "normal" adrenal were obtained at autopsy from 2 patients with no known adrenocortical dysfunction. All adrenal glands were removed at a one-stage operation and kept cold throughout all the experimental manipulations. All patients received cortisone acetate or cortisol hemisuccinate the evening prior to and the morning of surgery. Blood and cortisol were administered during the operative procedure.

\section{Case reports}

L.H., a 30 year old female, was referred to the Outpatient Clinic because of a 2-year history of fatigue, headache, amenorrhea, hypertension, emotional lability and decreased libido. Blood pressure was 196/145. Physical findings were: moon facies, plethora, diminished scalp hair, purple striae, hirsutism, truncal obesity. An acneiform eruption was present over the face, back and chest. Hemogram, urine analysis, electrolytes, nonprotein nitrogen, total protein, albumin/globulin ratios, fasting and 2-hour postprandial blood sugars were normal. An intravenous ACTH stimulation test was abnormal (Figure 1). Radiological examinations revealed calcification of the falx cerebri but no osteoporosis in the skull, long bones or vertebral column.

T.N. was a 12 year old boy referred to the Pediatric Service because of a "Cushingoid" appearance. $\mathrm{He}$ complained of headaches and frequent diaphoresis. Physical examination revealed a moon facies, plethora, purple striae, acanthosis nigricans, tinea versicolor, an acneiform 


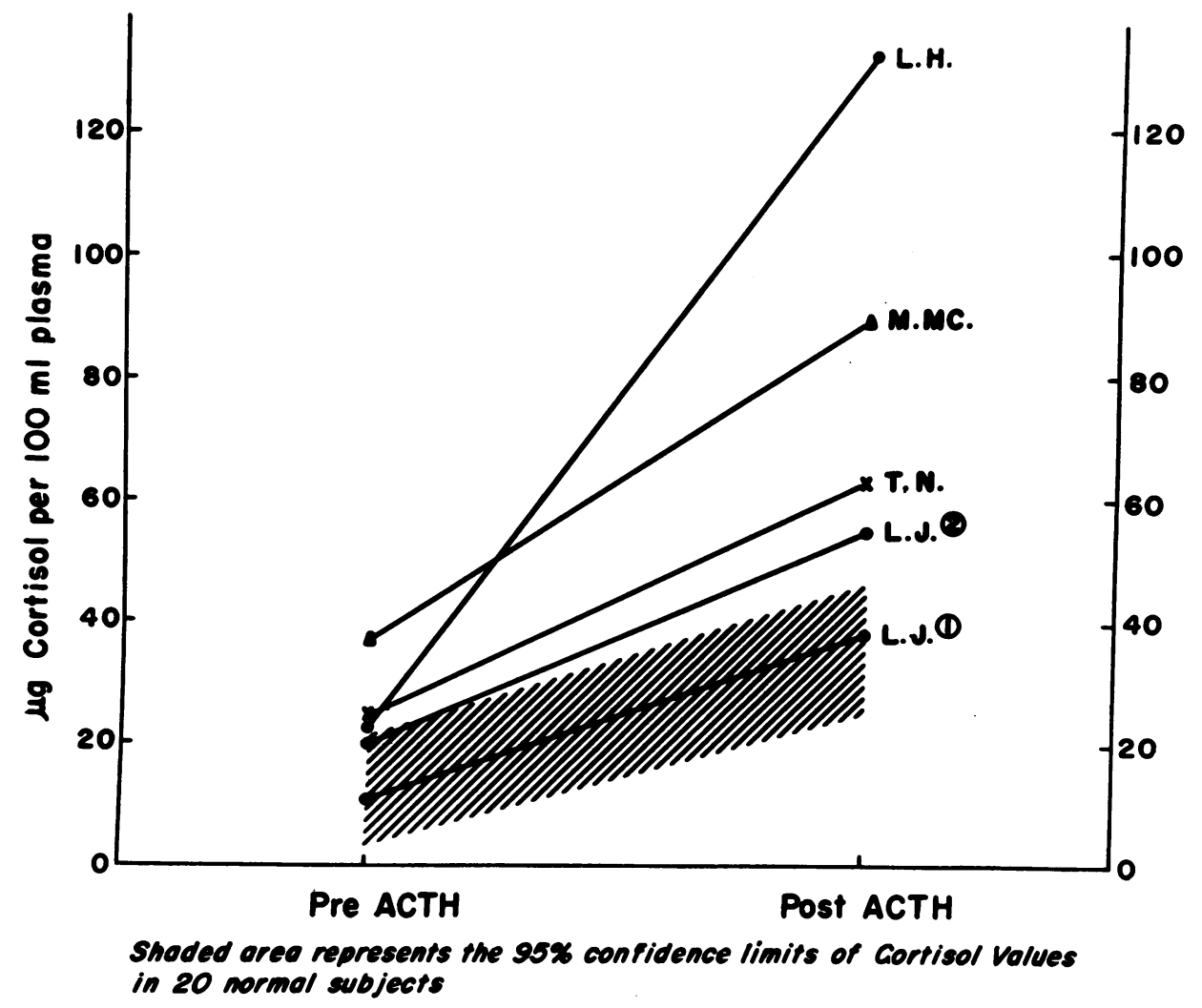

Fig. 1. Plasma cortisol response to ACTH in four patients with Cushing's SYNDROME.

eruption and truncal obesity. Blood pressure was 160/ 130. The hemoglobin was $17.8 \mathrm{~g}$ per $100 \mathrm{ml}$ and the hematocrit 48 per cent. The white blood cell count (WBC) was 14,350 per $\mathrm{mm}^{3}$. Electrolytes, nonprotein nitrogen, fasting and 2 -hour postprandial blood sugars, total protein, and albumin/globulin ratios, urine analysis, calcium, phosphorus and alkaline phosphatase were normal. X-ray examinations of the bones were normal. An intravenous ACTH stimulation test was abnormal (Figure 1).

L.J. was a 45 year old female with a 2 -year history of mental depression, easy bruisibility and fatigue, and a 1-year history of headache and poor wound healing. Positive physical findings were: blood pressure 180/100, moon facies, plethora, purple striae, truncal obesity, peripheral edema, telangiectasis and acneiform eruption over the face. The WBC was 17,000 per $\mathrm{mm}^{3}$. Hemoglobin, hematocrit, urine analysis, electrolytes and blood chemistries were within normal limits. X-ray examination of skull and ribs revealed osteoporsis. The first ACTH test was normal, the second test performed 3 months later showed an abnormal increment in plasma cortisol.

M.Mc. was a 42 year old female with a 4-year history of easy bruisibility, fatigue, headache, poor wound healing, amenorrhea and hypertension. Physical examination revealed blood pressure of $210 / 110$, moon facies, plethora, alopecia, hirsutism, purple striae, truncal obesity with obese extremities, diffusely enlarged thyroid gland, peripheral edema, left ventricular enlargement and an acneiform eruption over the face, back and chest. The patient had a diabetic type of glucose tolerance curve and glycosuria. Plasma cortisol levels were abnormal before and after ACTH stimulation. X-ray examination of the skull, long bones, pelvis and vertebral column revealed osteoporosis of the skull and a compression fracture of the fifth lumbar vertebra. The patient refused surgery and returned to the hospital 3 weeks later in an acute depressive psychotic state associated with early left-sided congestive heart failure. After treatment of the heart failure with a low-salt diet, digitalis and mercurial diuretics, surgery was performed. A large adrenal adenoma was discovered.

E.W., a 47 year old female secretary, entered the hospital for "blurred vision"; 24 years before admission the patient was treated for a urinary tract infection. Fifteen years prior to entry, the patient was told that she had hypertension; blood pressure at that time was 230/110. The patient had diabetes mellitus managed by diet alone. Physical examination revealed a blood pressure of $260 / 130$, bilateral papilledema, retinal hemorrhages and exudates but no microaneurysms, left ventricular en- 
largement, mitral insufficiency and a normal sinus rhythm. There was no evidence of congestive heart failure. Diagnostic studies for pheochromocytoma, hyperaldosteronism and unilateral renal disease were unrevealing. Urinary excretion of 17 -ketosteroids and 17-ketogenic steroids were normal. Serum potassium was $2.6 \mathrm{mEq}$ per $\mathrm{L}$, serum sodium $139 \mathrm{mEq}$ per $\mathrm{L}$, chloride $91 \mathrm{mEq}$ per $\mathrm{L}$, and $\mathrm{CO}_{2} 33 \mathrm{mEq}$ per $\mathrm{L}$. It was felt that the low serum potassium was caused by chlorothiazide therapy. The serum potassium returned to normal on a routine diet without potassium supplementation. Nonprotein nitrogen was $57 \mathrm{mg}$ per $100 \mathrm{ml}$. The patient had $11.5 \mathrm{~g}$ per $100 \mathrm{ml}$ hemoglobin and 35 per cent hematocrit. Urine cultures were sterile. Because of the progressively malignant nature of the hypertension, a bilateral adrenalectomy was performed. Both adrenals were enlarged. The blood pressure decreased significantly, but the patient experienced an acute myocardial infarction on the third postoperative day and succumbed. An autopsy confirmed the clinical cause of death.

J.K., a 41 year old male, was admitted to the hospital because of increased "nervousness, sweating and tachycardia" of about 2 years' duration. The patient claimed to have been "nervous" for many years. Two months prior to admission an elevated blood pressure of $170 / 110$ was found, associated with increased urinary catecholamines. Aside from the elevated blood pressure on admission, physical examination was normal. Additional measurements of catecholamine excretion in the hospital were normal as were other diagnostic studies. An intravenous pyelogram showed an absent left kidney and ureter, and a mass in the region of the left adrenal. A careful surgical exploration revealed that the left kidney, adrenal gland and mass were indeed absent. The patient was unimproved upon discharge. He returned 1 month later and an exploration of the right adrenal gland with subsequent total removal was performed. The adrenal weight was within normal limits. Surgical exploration at that time revealed no evidence for argentiform tumor. Again the patient did not experience symptomatic improvement. He was later admitted to the West Haven VA Hospital where investigation revealed normal adrenocortical and adrenomedullary function, presumably on the basis of an ectopic adrenal gland. His blood pressure was labile but generally within the normal range.

Incubation technique. Adrenals were immediately weighed, sectioned, freed of fat, reweighed, and sliced with a Stadie-Riggs microtome. Slices from multiple areas of each adrenal were taken for each experimental flask. Medullary tissue was not removed. Incubation of weighed slices was performed in a Dubnoff metabolic incubator for 3 hours at $37^{\circ} \mathrm{C}$ in $1 \mathrm{ml}$ per $30 \mathrm{mg}$ of tissue of Krebs-Ringer bicarbonate buffer with $200 \mathrm{mg}$ per $100 \mathrm{ml}$ glucose in an atmophere of 95 per cent $\mathrm{O}_{2}, 5$ per cent $\mathrm{CO}_{2}$. The incubations were begun within 3 hours after excision of the adrenals. Five to $10 \mathrm{U}$ of ACTH per $\mathrm{g}$ of tissue was added to selected incubation flasks. Tracer quantities of progesterone-16- $\mathrm{H}^{3}$ and corticoster-
one-4-C $C^{14}$, purified to constant specific activity by paper chromatography, were added to some experimental flasks. After incubation the media were carefully decanted and the tissue and flasks washed three times with cold isotonic saline and appropriate media pooled. In order to correct for chemical losses incurred during manipulations, tracer quantities of $\mathrm{C}^{\mathbf{1 4}}$-labeled cortisol and corticosterone, and tritium-labeled aldosterone were added to the media (except those from the incorporation studies). Because corticosterone and 11-deoxycortisol were carried through the same chromatographic systems and had similar mobilities except for approximately $3 \mathrm{~cm}$ separation on a second chromatogram, it was assumed that the recoveries of corticosterone and 11-deoxycortisol were similar. Therefore, the recoveries of the added tracer $\mathrm{C}^{14}$-corticosterone were also used to correct for chemical losses of 11-deoxycortisol.

Separation and measurement of corticosteroids. The media were extracted twice with 2 vol of dichloromethane which had been purified by passage through a silica-gel column. The dichloromethane extract was washed once with 0.1 vol of $0.05 \mathrm{~N} \mathrm{NaOH}$, twice with 0.1 vol of distilled water, dried with anhydrous sodium sulfate, and evaporated in vacuo at $37^{\circ} \mathrm{C}$. The residues were applied to Whatman no. 1 chromatography paper, along with appropriate standards, and developed for 72 hours in a modification of the toluene: propylene: glycol system of Burton, Zaffaroni and Keutmann (15). The effluents were collected. Corticosteroids were located on the chromatograms by the ultraviolet scanning method. The cortisol and cortisone-aldosterone areas were eluted separately with absolute ethanol and rechromatographed in the Bush-C system (16) which separated cortisone and aldosterone. The effluents from the toluene-propylene glycol system were chromatographed for 20 hours in the cyclohexane: dioxane: methanol: water system (100:100: $50: 25)$ which separated corticosterone from 11-dexoycortisol (17). $C^{14}$-labeled steroids were also located on the chromatograms by a gas-flow paper chromatogram scanner with a thin window. Identical mobilities were observed by the ultraviolet absorbing and radioactive strip scanning techniques.

Quantitative measurements of the isolated corticosteroids were performed on eluates from the second chromatographic systems by the alkaline fluorescent method of Abelson and Bondy (18). For each corticosteroid measured, the corresponding authentic steroid was used in construction of the standard curve, except in the case of aldosterone. The fluorescent curve of the latter was approximated more closely by corticosterone than by any of the available steroids tested (19).

Radioactivity was counted to a standard error of \pm 2 per cent in a liquid phosphor scintillation counter (model LP2, Technical Measurements Corp., New Haven, Conn.) which has a counting efficiency of 64 to 68 per cent for $\mathrm{C}^{14}$ and 13 to 18 per cent for tritium. Progesterone- $16-\mathrm{H}^{3}$, 500 -mc per mmole (obtained from $\mathrm{New}$ England $\mathrm{Nu}$ clear Corp.), was mixed with stable progesterone, and purified by paper chromatography. Corticosterone-4-C $\mathrm{C}^{\mathbf{1 4}}$, 
$1.47 \mathrm{mc}$ per mmole, and cortisol-4-C $\mathrm{C}^{\mathbf{1 4}}, 1.47 \mathrm{mc}$ per mmole (obtained from the Endocrinology Study Section, USPHS), were also purified by paper chromatography and their specific activities determined prior to use. Randomly labeled $\mathrm{H}^{3}$-aldosterone was prepared from aldosterone-21-monoacetate by the Wilzbach technique and purified by paper chromatography as both the monoacetate and the free alcohol.

The isolated corticosteroids were identified by virtue of their characteristic mobilities in two to three different chromatographic systems, ultraviolet absorption, fluorescence in alkaline solution and, in some instances, maximal ultraviolet absorption at 240 to $242 \mathrm{~m} \mu$, and blue tetrazolium reaction. In the incorporation studies, several samples of $\mathrm{H}^{3}$-cortisol and $\mathrm{H}^{3}$-corticosterone which were synthesized from progesterone-16- $\mathrm{H}^{3}$ were further characterized after elution from the second chromatogram. $\mathrm{H}^{3}$-cortisol was chromatographed in the $\mathrm{E}_{2} \mathrm{~B}$ system (20), then mixed with authentic $\mathrm{C}^{14}$-cortisol and the ratio of $\mathrm{H}^{3}: \mathrm{C}^{14}$ determined after further chromatography as the monoacetate in the carbon tetrachloride: methanol: water system and the cyclohexane: dioxane: methanol: water system (17). The $\mathrm{H}^{3}$-corticosterone was chromatographed on the $\mathrm{E}_{2} \mathrm{~B}$ system and its specific activity remeasured.

\section{RESULTS}

In Figure 1 are represented the pre- and postACTH stimulation levels of plasma cortisol of four patients with Cushing's syndrome. The preACTH levels were abnormally high in L.H., M.Mc. and T.N. There was an exaggerated response to ACTH stimulation in all, although the first responses of L.J. were within normal limits despite the presence of classical signs of Cushing's syndrome.

In Table $I$ is shown the steroid production by adrenal tissue from patients without Cushing's syndrome and by the ipsilateral atrophic gland of Patient L.J. with the syndrome. The first two
TABLE I

Steroid production by postmortem, "normal," atrophic and "hypertensive" adrenal glands

\begin{tabular}{|c|c|c|c|c|c|c|c|}
\hline \multirow[b]{2}{*}{ Patient } & \multirow[b]{2}{*}{ Pathology } & \multirow{2}{*}{$\begin{array}{l}\text { Weight, } \\
\text { inc. } \\
\text { tissue }\end{array}$} & \multicolumn{5}{|c|}{ Steroids* } \\
\hline & & & F & $E$ & Aldo & B & 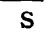 \\
\hline & & $m g$ & & & $g / 3 h$ & & \\
\hline A & PM† adenoma & 1,037 & $\mathbf{0}$ & 0 & 0 & $\mathbf{0}$ & \\
\hline B & PM adrenal $\ddagger$ & 1,010 & $\mathbf{0}$ & $\mathbf{0}$ & $\mathbf{0}$ & $\mathbf{0}$ & \\
\hline J.K. & "Normal" & 1,661 & 42.5 & 3.5 & 1.8 & 14.6 & 2.5 \\
\hline L.J. & $\begin{array}{l}\text { Atrophic, plus } \\
\text { ACTH }\end{array}$ & $\begin{array}{l}984 \\
\mathbf{4 7 4}\end{array}$ & $\begin{array}{r}66.4 \\
133.0\end{array}$ & $\begin{array}{l}4.9 \\
3.4\end{array}$ & $\begin{array}{l}3.6 \\
6.2\end{array}$ & $\begin{array}{l}11.7 \\
13.8\end{array}$ & $\begin{array}{l}1.6 \\
2.1\end{array}$ \\
\hline E.W. & Lt., hypertension & 573 & 60.4 & 0.6 & 2.3 & 22.8 & 5.6 \\
\hline E.W. & Rt., hypertension & 570 & 50.0 & 0.4 & 1.8 & 10.5 & 2.3 \\
\hline
\end{tabular}

*F, cortisol; E, cortisone; Aldo, aldosterone; B, corticosterone; S, 11-deoxycortisol.

PM, postmortem.
TPN, glucose-6-phosphate and human serum added to media; in IPN, glucose-6-

glands were obtained at autopsy (indicated by $P M)$. The adrenal tissue was obtained within 3 hours after death and maintained at $4^{\circ} \mathrm{C}$ until incubated, approximately 12 hours later. Despite the addition of cofactors to gland $B$ no steroids could be detected in the incubation media. Nevertheless, it is possible that in all the incubation studies with fresh tissue, small amounts of steroids present within the glands prior to incubation contributed to the total quantities found in the incubation media. The results from the adrenal of J.K. represent the pattern of production by "normal" tissue. Cortisol, corticosterone, cortisone, aldosterone and 11-deoxycortisol were detected. Cortisol was the major steroid produced and corticosterone was the second. An atrophic gland from Patient L.J. with Cushing's syndrome produced amounts of steroids within 3 hours comparable with those of the "normal" and "hyper-

TABLE II

Steroid production by hyperplastic or adenomatous tissue from patients with Cushing's syndrome

\begin{tabular}{|c|c|c|c|c|c|c|c|c|c|c|c|c|c|}
\hline \multirow[b]{2}{*}{ Patient } & \multirow[b]{2}{*}{ Pathology } & \multirow{2}{*}{$\begin{array}{l}\text { Weight, } \\
\text { inc. } \\
\text { tissue }\end{array}$} & \multicolumn{5}{|c|}{ Steroids } & \multirow{2}{*}{$\begin{array}{l}\text { Weight, } \\
\text { inc. } \\
\text { tissue }\end{array}$} & \multicolumn{5}{|c|}{ Steroids with ACTH } \\
\hline & & & F & $\mathrm{E}$ & Aldo & B & $\mathbf{S}$ & & F & $\mathrm{E}$ & Aldo & B & $\mathrm{S}$ \\
\hline & & $m g$ & \multicolumn{5}{|c|}{$\mu g / g / 3 \mathrm{hrs}$} & $m g$ & \multicolumn{5}{|c|}{$\mu g / g / 3 \mathrm{hrs}$} \\
\hline L.H. & $\begin{array}{l}\text { Rt., hyperplasia } \\
\text { Lt., hyperplasia } \\
\text { Adenoma }\end{array}$ & $\begin{array}{l}1,005 \\
1,025 \\
1,845\end{array}$ & $\begin{array}{l}50.8 \\
40.8 \\
19.2\end{array}$ & $\begin{array}{l}3.3 \\
4.2 \\
3.3\end{array}$ & $\begin{array}{l}\mathbf{0} \\
\mathbf{0} \\
\mathbf{0}\end{array}$ & $\begin{array}{r}12.3 \\
3.5\end{array}$ & $\begin{array}{l}4.5 \\
1.1\end{array}$ & $\begin{array}{r}1,010 \\
500 \\
1,200\end{array}$ & $\begin{array}{l}76.5 \\
94.8 \\
75.4\end{array}$ & $\begin{array}{r}5.8 \\
8.6 \\
11.8\end{array}$ & $\begin{array}{l}\mathbf{0} \\
\mathbf{0} \\
\mathbf{0}\end{array}$ & $\begin{array}{r}13.8 \\
6.4 \\
38.8\end{array}$ & $\begin{array}{l}8.0 \\
1.1 \\
3.0\end{array}$ \\
\hline T.N. & $\begin{array}{l}\text { Rt., hyperplasia } \\
\text { Lt., hyperplasia }\end{array}$ & $\begin{array}{l}2,056 \\
2,482\end{array}$ & $\begin{array}{l}73.5 \\
80.6\end{array}$ & $\begin{array}{l}5.3 \\
3.9\end{array}$ & $\begin{array}{l}0.8 \\
1.1\end{array}$ & $\begin{array}{l}12.0 \\
16.9\end{array}$ & $\begin{array}{l}1.9 \\
3.0\end{array}$ & $\begin{array}{l}2,008 \\
2,532\end{array}$ & $\begin{array}{l}110 \\
111\end{array}$ & $\begin{array}{l}5.0 \\
7.4\end{array}$ & $\begin{array}{l}0.9 \\
1.2\end{array}$ & $\begin{array}{l}19.9 \\
18.0\end{array}$ & $\begin{array}{l}5.4 \\
6.4\end{array}$ \\
\hline L.J. & Adenoma & 1,554 & 88.6 & 5.0 & $\mathbf{0}$ & 2.6 & 1.0 & 1,544 & 157 & 11.8 & 0.4 & 10.8 & 2.3 \\
\hline M.Mc. & Adenoma & 2,015 & 22.2 & $\mathbf{0}$ & $\mathbf{0}$ & & & $\begin{array}{l}945 \\
931\end{array}$ & $\begin{array}{l}25.3 * \\
33.9 \dagger\end{array}$ & $\begin{array}{l}\mathbf{0} \\
\mathbf{0}\end{array}$ & $\begin{array}{l}\mathbf{0} \\
\mathbf{0}\end{array}$ & & \\
\hline
\end{tabular}

* $100 \mathrm{mU}$ ACTH.

$+1,000 \mathrm{mU}$ ACTH. 
tensive" glands. The addition of ACTH in vitro resulted in a twofold increment in cortisol production. Adrenal tissue from both left and right adrenals of Patient E.W. with malignant hypertension did not have an excessive rate of aldosterone production when expressed as $\mu \mathrm{g}$ per $\mathrm{g}$ per 3 hours. Actually, the atrophic gland had the highest production in $\mu \mathrm{g}$ per $\mathrm{g}$ per 3 hours.

Hyperplastic and adenomatous tissue from patients with Cushing's syndrome. The results of the incubation of hyperplastic and adenomatous tissue from these patients are listed in Table II. Slices from the two large hyperplastic glands of L.H. produced a corticosteroid pattern similar to the tissue removed from patients without Cushing's syndrome except for the failure to form aldosterone. The adenoma, however, produced much less cortisol and corticosterone per gram of tissue. The adenoma removed from M.Mc. also produced only a small amount of cortisol per gram of tissue. However, the adenoma from L.J. had the highest cortisol production per gram of tissue per 3 hours in this group but made only small amounts of corticosterone ( $\mathrm{F} / \mathrm{B}$ ratio 36 to 1 ) and no detectable aldosterone. The hyperplastic glands of T.N. were the only tissue which produced measurable amounts of aldosterone prior to ACTH stimulation. Aside from the somewhat increased quantities of cortisol production by the tissue of T.N. and L.J., the quantities produced per gram tissue per 3 hours of incubation of the other steroids were not greater than the rate by tissue from the patients without Cushing's syndrome.

The addition of ACTH to the incubation media resulted in an increased release of cortisol in every gland studied. The increments in production of other steroids were not so striking. All three adenomas responded to $\mathrm{ACTH}$ in vitro; at least two responded in vivo. The response of L.H. was difficult to interpret because of the presence of the two hyperplastic glands. The adenoma of L.H., which was associated also with bilateral adrenal hyperplasia, was responsive to $\mathrm{ACTH}$ in vitro and showed nearly a 4-fold increment in cortisol and an 11-fold increment in corticosterone release. No aldosterone was detectable in any incubation media of tissue from L.H. The adenoma from L.J. produced only a minimal quantity of aldosterone after ACTH stimulation, even though the ipsilateral atrophic adrenal had the highest aldosterone production in $\mu \mathrm{g}$ per $\mathrm{g}$ per 3 hours' incubation of any tissue. In none of the studies with tissue from patients with Cushing's syndrome or from the patient with malignant hypertension was an excessive amount of aldosterone produced per gram of tissue per 3 hours' incubation.

TABLE III

Total steroid production per gland

\begin{tabular}{|c|c|c|c|c|c|c|c|c|c|c|c|c|c|c|}
\hline \multirow[b]{2}{*}{ Patient } & \multirow[b]{2}{*}{ Pathology } & \multirow{2}{*}{$\begin{array}{l}\text { Total } \\
\text { wt, } \\
\text { tissue }\end{array}$} & \multicolumn{6}{|c|}{ Steroids } & \multicolumn{6}{|c|}{ Steroids (with ACTH) } \\
\hline & & & F & $\mathrm{E}$ & Aldo & B & $\mathrm{S}$ & Total & F & $\mathrm{E}$ & Aldo & B & $\mathrm{s}$ & Total \\
\hline & & $g$ & \multicolumn{6}{|c|}{ total $\mu \mathrm{g} / \mathrm{gland} / 3 \mathrm{hrs}$} & \multirow{2}{*}{\multicolumn{6}{|c|}{ total $\mu \mathrm{g} / \mathrm{gland} / 3 \mathrm{hrs}$}} \\
\hline J.K. & Normal & 8.3 & 353 & 29 & 14.9 & 121 & 20.8 & 539 & & & & & & \\
\hline L.J. & Atrophic & 3.0 & 199 & 15 & 10.8 & 35 & 4.8 & 265 & 399 & 10 & 19 & 41 & 6 & 475 \\
\hline E.W. & $\begin{array}{l}\text { Lt., hypertension } \\
\text { Rt., hypertension }\end{array}$ & $\begin{array}{l}16.0 \\
12.5\end{array}$ & $\begin{array}{l}966 \\
625\end{array}$ & $\begin{array}{l}9.6 \\
5.0\end{array}$ & $\begin{array}{l}36.8 \\
22.5\end{array}$ & $\begin{array}{l}365 \\
131\end{array}$ & $\begin{array}{l}90 \\
29\end{array}$ & $\begin{array}{r}1,467 \\
813\end{array}$ & & & & & & \\
\hline L.H. & $\begin{array}{l}\text { Rt., hyperplasia } \\
\text { Lt., hyperplasia } \\
\text { Adenoma }\end{array}$ & $\begin{array}{l}12.5 \\
13.5 \\
32.0\end{array}$ & $\begin{array}{l}635 \\
551 \\
614\end{array}$ & $\begin{array}{r}41 \\
57 \\
106\end{array}$ & $\begin{array}{l}0 \\
0 \\
0\end{array}$ & $\begin{array}{l}154 \\
112\end{array}$ & $\begin{array}{l}56 \\
35\end{array}$ & $\begin{array}{l}886 \\
608^{*} \\
867\end{array}$ & $\begin{array}{r}956 \\
1,280 \\
2,413\end{array}$ & $\begin{array}{r}73 \\
116 \\
378\end{array}$ & $\begin{array}{l}0 \\
0 \\
0\end{array}$ & $\begin{array}{r}173 \\
86 \\
1,242\end{array}$ & $\begin{array}{l}100 \\
14.9 \\
96\end{array}$ & $\begin{array}{l}1,302 \\
1,497 \\
4,129\end{array}$ \\
\hline T.N. & $\begin{array}{l}\text { Rt., hyperplasia } \\
\text { Lt., hyperplasia }\end{array}$ & $\begin{array}{l}14.5 \\
11.5\end{array}$ & $\begin{array}{r}1,066 \\
927\end{array}$ & $\begin{array}{l}77 \\
45\end{array}$ & $\begin{array}{l}12 \\
13\end{array}$ & $\begin{array}{l}174 \\
195\end{array}$ & $\begin{array}{l}28 \\
35\end{array}$ & $\begin{array}{l}1,357 \\
1,214\end{array}$ & $\begin{array}{l}1,595 \\
1,277\end{array}$ & $\begin{array}{l}73 \\
85\end{array}$ & $\begin{array}{l}13 \\
14\end{array}$ & $\begin{array}{l}289 \\
207\end{array}$ & $\begin{array}{l}78 \\
74\end{array}$ & $\begin{array}{l}2,048 \\
1,657\end{array}$ \\
\hline L.J. & Adenoma & 22.0 & 1,949 & 110 & 0 & 57 & 22 & 2,138 & 3,454 & 260 & 9 & 238 & 51 & 4,012 \\
\hline M.Mc. & Adenoma & 26.0 & 577 & 0 & 0 & & & $577^{*}$ & $881 \dagger$ & 0 & 0 & & & $881^{*}$ \\
\hline
\end{tabular}

* This total does not include any corticosterone and 11-deoxycortisol that might have been formed.

$\dagger 1,000 \mathrm{mU}$ ACTH was added to the incubation media. 
Total steroid production. The total corticosteroid production per gland by all tissues is shown in Table III. These results are based on the assumption that the incubated tissue was representative of the entire gland. The total production of the most potent glucocorticoid, cortisol, by the hyperplastic and adenomatous tissues was consistently greater than that of the "normal" and atrophic adrenal glands. The total production of cortisol by the adrenals from the patient with malignant hypertension was in the range of the values from the patients with Cushing's syndrome.

There was no direct correlation between the total pre- and post-ACTH cortisol production in vitro with the in vivo pre- and post-ACTH plasma cortisol levels. In fact, those patients with the highest post-ACTH plasma cortisol levels did not always have the highest total cortisol production in vitro.

The quantity of corticosterone produced by the adenoma of L.H. was markedly elevated after incubation in the presence of ACTH. This steroid could not be measured by the usual clinical methods for evaluating adrenocortical function. Although all the patients with Cushing's syndrome had significant hypertension, little or no aldosterone per gland was produced. The left adrenal of E.W. had the highest basal production of corticosterone and 11-deoxycortisol of any gland incubated.

Incorporation studies. In Table IV are listed the incorporation data from incubation of adrenal slices with corticosterone-4-C $\mathrm{C}^{14}$ and progesterone16- $\mathrm{H}^{3}$. Radioactive cortisol, corticosterone, and aldosterone were isolated from the media. Radioactive and chemical measurements of each compound were made after the second chromatography. Although the specific activities of progesterone- $16-\mathrm{H}^{3}$ and corticosterone-4- $\mathrm{C}^{14}$ substrates were constant with separate slices from the same adrenal, they were not constant between experiments with different adrenal glands. This should not influence the comparison of results appreciably, since the smallest ratio by weight of tissue to substrate was approximately 8,600 to 1. In order to compare the incorporation results, the ratio of the specific activity (SA) of the product to that of the substrate is expressed. Although no correction for chemical losses or the possible effect of substrate was made, no striking difference was observed in the amounts of steroids produced per $g$ per 3 hours' incubation by the different tissue slices of each adrenal in the control (Tables I and II) and incorporation studies. There was only one exception, with the adenoma from L.J. In this experiment, the control studies resulted in a higher amount produced per $g$ per 3 hours' incubation (Table II) than did the incorporation studies. As can be seen, similar SA and per cent of incorporations resulted when separate slices of an adrenal gland were incubated with the same precursor.

Although radiochemical purity has not been demonstrated for all the steroids isolated, further purification of several samples of cortisol-16- $\mathrm{H}^{3}$ and corticosterone- $16-\mathrm{H}^{3}$ revealed that measurements of SA after the second chromatogram are reasonably valid.

In Table $\mathrm{V}$ is shown a slight decrease in the specific activities of cortisol between the second and third chromatogram. Additon of authentic $\mathrm{C}^{14}$-cortisol, followed by acetylation and two subsequent chromatographies, showed a further removal of minimal amounts of tritium impurities. None of these changes, however, is great enough to alter significantly the interpretation of the results.

Carrier corticosterone was added to several samples of corticosterone-16- $\mathrm{H}^{3}$ after the second chromatography system; specific activities were measured and the samples were processed in a third chromatography system. Table VI shows that there was very little change in SA between the two chromatograms.

Radioactive progesterone was readily incorporated into cortisol. Of each $10 \mu \mathrm{g}$ of cortisol synthesized, approximately $1 \mu \mathrm{g}$ came from the progesterone in the media. When corticosterone4-C ${ }^{14}$ was the substrate, only small amounts of radioactivity were present in the cortisol area of the second paper chromatogram. Subsequent purification separated most of this radioactivity from cortisol. Although there was a higher percentage of incorporation of progesterone into cortisol than into corticosterone, the SA, and the ratio of the SA of product to substrate, was greater for corticosterone than cortisol. These calculations indicate a higher incorporation per microgram produced. In three of the four incorpora- 


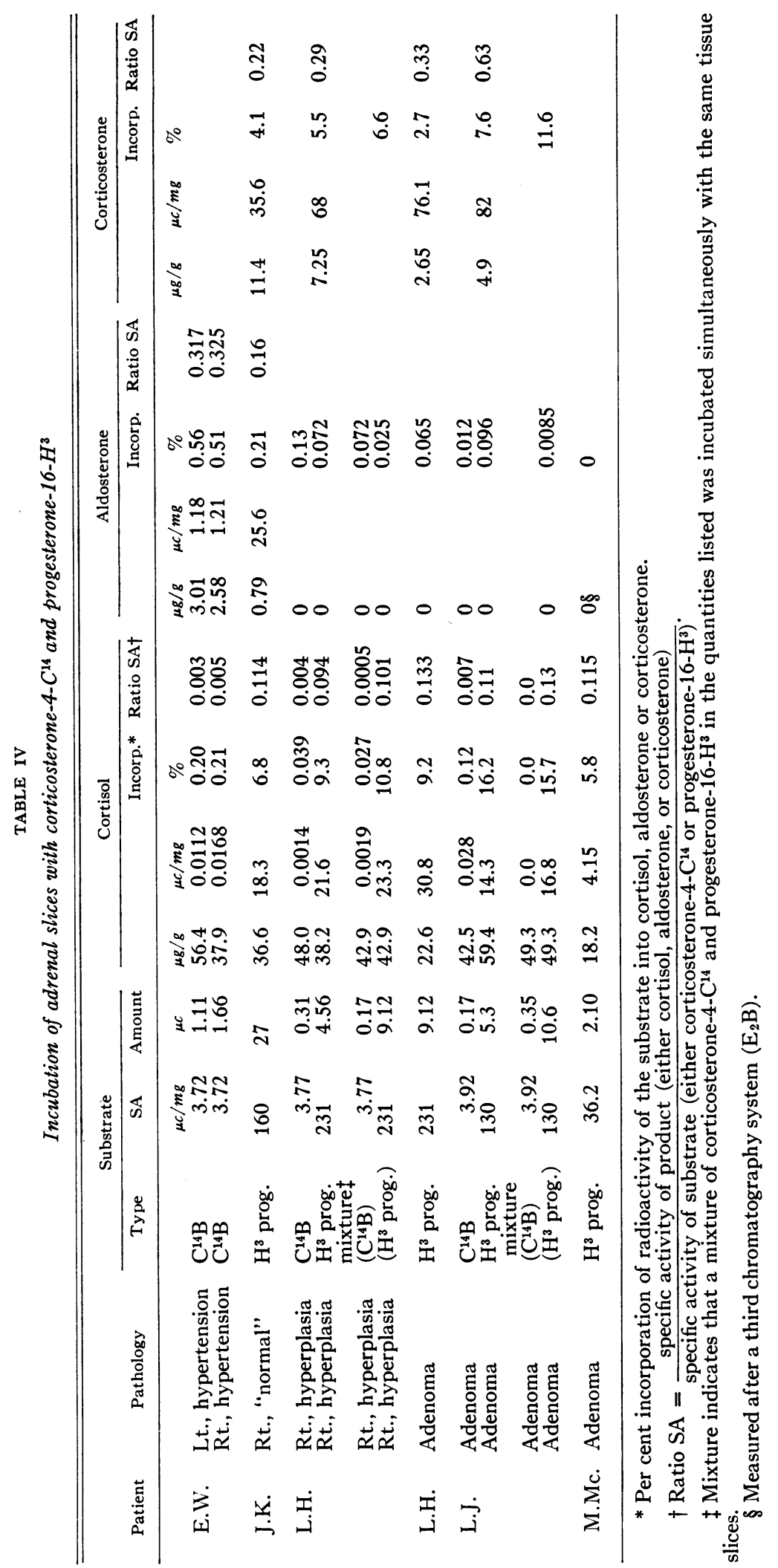


tion studies with adrenal slices from patients with Cushing's syndrome, there was a greater percentage of the progesterone- $16-\mathrm{H}^{3}$ incorporated into cortisol than by the slices from the "normal" adrenal gland.

A comparison of aldosterone biosynthesis from progesterone- $16-\mathrm{H}^{3}$ or corticosterone- $4-\mathrm{C}^{14}$, by the normal and hypertensive tissue, is of interest. When corticosterone-4- $\mathrm{C}^{14}$ was used as a substrate, the tissue incorporated a greater percentage of the radioactivity into aldosterone and produced more aldosterone per gram of tissue; also a higher ratio of SA of product to substrate was observed. However, when progesterone-16- $\mathrm{H}^{3}$ was the substrate, the SA of the radioactive aldosterone produced was 72 per cent of the SA of the cortico-

TABLE V

Purification of cortisol-16- $H^{3}$ synthesized from progesterone-16- $\mathrm{H}^{3}$

\begin{tabular}{|c|c|c|c|}
\hline \multirow[b]{2}{*}{ System } & \multicolumn{3}{|c|}{ Specific activity } \\
\hline & J.K.* & L.J. & L.J. \\
\hline \multirow{4}{*}{$\begin{array}{l}\text { Toluene :propylene :glycol } \dagger \\
\text { Bush-C } \\
\mathrm{E}_{2} \mathrm{~B}\end{array}$} & \multicolumn{3}{|c|}{$\mu c / m g$} \\
\hline & 18.3 & 16.8 & 14.3 \\
\hline & 14.0 & 15.3 & 13.6 \\
\hline & \multicolumn{3}{|c|}{$\begin{array}{l}\text { Addition of authentic } \\
\mathrm{C}^{14} \text {-cortisol }\end{array}$} \\
\hline \multicolumn{4}{|c|}{ Ratio $\mathrm{H}^{3}: \mathrm{C}^{14}$} \\
\hline \multicolumn{4}{|c|}{ Acetylation } \\
\hline $\begin{array}{l}\text { Carbon tetrachloride: } \\
\text { methanol: water }(4: 4: 1)\end{array}$ & 5.34 & 5.22 & 5.24 \\
\hline $\begin{array}{l}\text { Cyclohexane: dioxane: } \\
\text { methanol: water } \\
(4: 4: 2: 1)\end{array}$ & 5.22 & 5.10 & 5.19 \\
\hline
\end{tabular}

* Initials J.K., L.J., L.J. and the specific activities indicate which of the samples listed in Table IV underwent the further purification.

† Specific activity was not measured after the first chromatography system.

TABLE VI

Purification of corticosterone-16- $H^{3}$ synthesized from progesterone-16- $H^{3 *}$

\begin{tabular}{|c|c|c|c|c|}
\hline \multirow[b]{2}{*}{ System } & \multicolumn{4}{|c|}{ Specific activity } \\
\hline & J.K. & L.H. & $\begin{array}{c}\text { L.H. } \\
\text { (Adenoma) }\end{array}$ & L.J. \\
\hline \multirow{3}{*}{$\begin{array}{l}\text { Toluene:propylene :glycol } \\
\text { Cyclohexane :dioxane: } \\
\text { methanol :water }(4: 4: 2: 1) \\
\mathrm{E}_{2} \mathrm{~B}\end{array}$} & \multicolumn{2}{|c|}{$\mu c / m g$} & \multicolumn{2}{|c|}{$\mu \mathrm{c} / \mathrm{mg}$} \\
\hline & 8.94 & 1.17 & 1.39 & 2.32 \\
\hline & 7.88 & 1.16 & 1.32 & 2.38 \\
\hline
\end{tabular}

* See footnotes to Table V.
TABLE VII

Ratios of cortisol to corticosterone in relation to micrograms produced and per cent incorporation after incubation of adrenal slices with $H^{3}$-progesterone *

\begin{tabular}{lcc}
\hline \multicolumn{1}{c}{ Gland } & \multicolumn{2}{c}{ Cortisol :corticosterone } \\
\hline & $\mu g$ produced & \% incorp. \\
Normal (J.K.) & 3.2 & 1.7 \\
Hyperplasia (L.H.) & 5.3 & 1.7 \\
Adenoma (L.H.) & 8.5 & 3.4 \\
Adenoma (L.J.) & 12.1 & 2.1 \\
\hline
\end{tabular}

* Data calculated from results in Table IV.

sterone- $16-\mathrm{H}^{3}$ produced. The results from the tissue of patients with Cushing's syndrome are difficult to interpret. Although radioactivity was found in the aldosterone area, insufficient aldosterone was produced for chemical measurement. Thus, specific activities could not be calculated or compared with the normal and hypertensive tissue.

In Table VII are listed the ratios of cortisol: corticosterone in relation to micrograms produced and per cent incorporation after incubation of adrenal slices with progesterone-16- $\mathrm{H}^{3}$. These results have been calculated from the data in Table IV. In each experiment the ratio of the micrograms produced is much greater than that of the per cent incorporation or, in other words, the specific activity of the cortisol is less than the specific activity of corticosterone.

\section{DISCUSSION}

In the present study with human adrenal slices, cortisol, corticosterone, cortisone, 11-deoxycortisol and, in some instances, aldosterone were detected in the incubation media. Each of these compounds has been detected in human adrenal vein blood in roughly the proportions present in the incubation media, except for aldosterone. The proportion of aldosterone is generally much higher in adrenal incubation media, compared with adrenal vein blood $(8,21-23)$. The incorporation of radioactive precursors, response to $\mathrm{ACTH}$, and failure of postmortem glands to produce steroids are evidence for active synthesis and release, and not merely leaching of preformed steroids from the tissue, although it is proballe that snall amounts of steroids were present in the tissues prior to incubation. Neher (24) found 1.5 to $3.9 \mu \mathrm{g}$ of cortisol per $\mathrm{g}$ of tissue after ho- 
mogenization and extraction of the entire gland; these four normal human adrenals were removed 1 to 2 hours post mortem. Small amounts of cortisone, corticosterone and barely detectable quantities of aldosterone were also found. Neher also noted that two adrenal glands removed from a subject 12 hours after suicide contained barely detectable quantities of steroids. Since approximately $1 \mathrm{~g}$ of autopsy adrenal tissue slices was incubated in the present study, it does not seem likely that measurable amounts of the small quantities of preformed steroids would be extracted by mere incubation in buffer. Dyrenfurth, Lucis, Beck and Venning (11) have shown a rough correlation between the excretion of urinary steroids and the in vitro production of steroids by adrenal slices from patients with Cushing's syndrome. This technique therefore appears to be valid for studying adrenocortical function. The limited availability of normal and even "hypertensive" adrenals, however, restricts the comparison of the results of "Cushingoid" tissue with other tissue. Moreover, the rates of secretion in vitro calculated for 24 hours are much less than those reported in vivo (25).

The rates of production of cortisol, cortisone and corticosterone by the adrenal slices per gram tissue per 3 hours' incubation from the patients with Cushing's syndrome are in agreement with those of Dyrenfurth and co-workers (11), although these investigators found slightly more aldosterone. The results of Bailey, Slade, Lieberman and Luetscher (10) corroborate the present finding of little or no aldosterone produced in vitro by adrenals from patients with Cushing's syndrome.

Pattern, rate and total steroid production. No striking difference in the basal pattern of steroid production by the "normal," atrophic and hypertensive tissue was noted except that the adrenal tissue from three of the four patients with Cushing's syndrome produced little or no aldosterone. All were hypertensive but none had derangement of serum electrolytes. This failure to measure aldosterone in the incubation media of several glands may have been due to the small amount of tissue incubated and the losses incurred during purification (mean \pm SD per cent recovery of added $\mathrm{H}^{3}$-aldosterone $\left.=58 \pm 13\right)$. Although Dyrenfurth and colleagues (11) consistently found small amounts of aldosterone in the incubation media of adrenal tissue from patients with Cushing's syndrome, most of the glands they studied were within normal size by weight. Possibly these glands had less hyperplasia of the zona fasciculata and therefore more zona glomerulosa per gram of tissue. Nevertheless, our observation of minimal or absent aldosterone is consistent with the small area of zona glomerulosa that was seen histologically and is consistent with the findings of Bailey and co-workers (10). The zona glomerulosa has been reported to be the site of aldosterone production in the ox and rat $(13,14)$. However, even in normal subjects the zona glomerulosa is not always morphologically distinct (26). The hypertension in the patients with Cushing's syndrome cannot be attributed to excessive aldosterone or excessive deoxycorticosterone, since none of the latter was detected by ultraviolet scanning. The hypertension of these patients with Cushing's syndrome, therefore, may be due to the action of steroids other than mineralocorticoids. However, Dyrenfurth and colleagues reported a direct correlation between the severity of hypertension and the percentage of aldosterone of the total steroid production; yet there was a poor correlation when the aldosterone per gland or the rate of aldosterone production in micrograms per gram per hour was used as an index.

Comparison of steroid production per gram of tissue per 3 hours of incubation illustrates that the production rates were about the same for tissue from patients with or without Cushing's syndrome except for the two adenomas which had much lower production rates. However, calculation of the total production of cortisol, the most potent of the glucocorticoids, per gland indicated that the tissue from the patients with Cushing's syndrome produced more steroid than "normal" and atrophic tissue chiefly because the total adrenal mass was larger. This corroborates results of Symington and co-workers (2), who found that adrenal homogenates from patients with Cushing's syndrome had no greater $11 \beta$ hydroxylating activity per unit weight than had homogenates of normal tissue, and those of Bailey and colleagues (10) who reported no increased rate of production per unit weight by hyperplastic adrenals. These observations must not apply to all adrenal tissue of Cushing patients, since this syndrome 
may be associated with normal-sized glands, in which cases there may be a greater rate of production per unit weight or persistent steroid secretion without diurnal variation, as has been reported in some cases of Cushing's syndrome with adrenal hyperplasia (27). Dyrenfurth and associates (11) actually studied the in vitro production by normal-sized adrenals from patients with Cushing's syndrome and did not find an excessive rate of production per gram. Of particular interest are the results of the adrenal slice incubation from the patient with malignant hypertension. Although the production in micrograms per gram per 3 hours of all steroids is not high, the total quantity of cortisol produced falls into the production range of the patients with Cushing's syndrome. Moreover, the total quantity of aldosterone produced is much greater than the "normal" and atrophic tissue. Both of these findings are due to the large size of the glands. Although measurement of this patient's aldosterone excretion in one 24-hour urine specimen was only $3 \mu \mathrm{g}$, it has been shown by Laragh and co-workers (28) that patients with malignant hypertension generally have an increased rate of aldosterone secretion. Several workers (29-32) have shown that angiotensin causes an increase in aldosterone production in man and dog. One of the present authors (32) has shown that in the hypophysectomized dog angiotensin increased aldosterone and, to a lesser extent, glucocorticoid secretion. Since there are some reports that adrenal glands are enlarged in severe hypertension, it is intriguing to speculate that angiotensin not only increases the endogenous secretion but also causes growth of the glands.

All tissue from the Cushing patients, including the atrophic adrenal and the three adenomas, responded to ACTH in vitro. The response of the adenomas is further evidence against the use of an ACTH test clinically to distinguish between adenomas and hyperplasia. In fact, the two adenomas associated with adrenal atrophy showed a significant increment in plasma cortisol after ACTH in vivo. The single 32-gram adenoma associated with bilateral adrenal hyperplasia showed a marked increment in corticosterone production when stimulated by ACTH. Dorfman (33) has also described large amounts of corticosterone synthesized by an adrenal adenoma in vitro. The role of corticosterone in the pathogenesis of the symptoms of Patient L.H. is not obvious. Although corticosterone alone is not a potent gluco- or mineralocorticoid, it may have synergistic effects with other steroids. In vitro studies have shown that some tumors from patients with Conn's syndrome produce significant quantities of corticosterone as well as aldosterone $(10$, 34). Moreover, Ross (35) has demonstrated that corticosterone enhances the potassium-losing effect of aldosterone in man.

Incorporation studies. In both normal and abnormal tissue a larger percentage of progesterone$16-\mathrm{H}^{3}$ is incorporated into cortisol than into corticosterone. The specific activity of the corticosterone, however, is higher. As is shown in Table VII, the ratios in micrograms produced of cortisol to corticosterone are much greater than the ratios of the percentage of incorporation of progesterone-16- $\mathrm{H}^{3}$. This is surprising since, if progesterone were the common substrate for biosynthesis of cortisol and corticosterone, the two ratios should be similar. This finding is supported by the data of Eichhorn and Hechter (36, 37) which showed that incubation of radioactive progesterone with bovine adrenocortical homogenates in various media yielded corticosterone with a higher specific activity than cortisol, regardless of the relative quantities of steroid produced, while incubation with $\mathrm{C}^{14}$-cholesterol always produced cortisol with a higher SA than corticosterone. Moreover, Berliner, Berliner and Dougherty (7) found that a greater percentage of $\mathrm{C}^{14}$-progesterone was incorporated in vitro into corticosterone than into cortisol by adrenal tissue from patients with mammary carcinoma and Cushing's syndrome, even though more cortisol than corticosterone was actually produced. There are numerous possible explanations for such discrepancies between the chemical and radioactive ratios. They have been adequately discussed by Ayres and co-workers (38) in relation to the role of progesterone and corticosterone as precursors for aldosterone. Certain of these possibilities appear unlikely, in view of the present and other studies with human adrenal tissue.

It is unlikely that sufficient cortisol is formed prior to the incubation to dilute the cortisol synthesized from radioactive progesterone, since incubation of autopsy adrenal tissue failed to re- 
lease cortisol. Moreover, exhaustive extraction of normal and hyperfunctioning adrenal tissue by Neher (24) resulted in much less cortisol per gram of tissue than was released into the incubation media by a gram of adrenal in the present study. Nor is it likely that the rates of production of either cortisol or corticosterone changed significantly during the incubation period, since both Dyrenfurth (11) and Cooper (8) and their co-workers demonstrated that rates remained constant over several hours of incubation. Possible explanations, such as greater dilution of the radioactive progesterone products by a larger pool of intermediates in the cortisol biosynthetic pathway than in the corticosterone pathway, and differences in the rates of access of the substrate, radioactive progesterone, to the different enzyme sites involved in cortisol and corticosterone synthesis (37), cannot be excluded. However, a distinct possibility is that a portion of cortisol is synthesized by alternate pathways(s). which bypass progesterone.

Recently Weliky (39) reported that $17 \alpha-\mathrm{OH}-$ pregnenolone is incorporated into cortisol by sheep adrenal tissue in vitro. ${ }^{2}$ This supports the possibility that a certain amount of cortisol is produced by an additional pathway (s) which does not require progesterone, since $17 \alpha$-hydroxy-pregnenolone is not a precursor for progesterone (40).

These incorporation studies with human adrenal slices confirm the observations reported with bovine adrenal tissue that prior hydroxylations at the 11- and 21-carbon atoms prevent subsequent hydroxylation at the 17 -carbon atom $(36,41)$. The data substantiate this observation for abnormal human tissue as well, since incubation with corticosterone-4-C $\mathrm{C}^{14}$ of adrenal slices from the patients with Cushing's syndrome resulted in very little radioactivity in the cortisol area after the second paper chromatogram, and most of this radioactivity is separated from cortisol by a third chromatogram. These results differ from a preliminary report of the authors which mentioned that a small amount of corticosterone-4-C $\mathrm{C}^{14}$ was incorporated into cortisol (42).

\footnotetext{
2 Recently we have found this to hold true with human adrenal tissue also. Slices of a hyperplastic adrenal incorporated $17 \alpha-\mathrm{OH}$-pregnenolone- $\mathrm{H}^{3}$ into cortisol. Since unequivocal demonstration of radiochemical purity is still in progress, these results will be reported later.
}

Studies of aldosterone biosynthesis have yielded conflicting results regarding the most efficient precursor for aldosterone: corticosterone or progesterone $(38,43-46)$. Previous studies by the authors with human adrenal slices from patients with carcinoma of breast indicated that 1 to 3 per cent of the precursor $\mathrm{C}^{14}$-corticosterone was incorporated into aldosterone (47). In the present incorporation experiments, only the adrenal slices from patients without Cushing's syndrome synthesized sufficient aldosterone to be measured chemically. In Table $\mathrm{V}$ it is shown that 0.56 and 0.51 per cent of the $\mathrm{C}^{14}$-corticosterone substrate was incorporated into aldosterone, while 0.21 per cent of progesterone- $16-\mathrm{H}^{3}$ was incorporated. The ratios of SA aldosterone/SA substrate were also higher in the $\mathrm{C}^{14}$-corticosterone incubation experiments. However, in the progesterone experiment the SA aldosterone- $16-\mathrm{H}^{3}$ isolated from the incubation media was 72 per cent of the corticosterone-16- $\mathrm{H}^{3}$, suggesting that the main pathway for aldosterone synthesis from progesterone is through corticosterone. This observation is in agreement with the findings of Ayres and associates (38). The failure to demonstrate identical specific activities of aldosterone and corticosterone might be explained by dilution with nonisotopic aldosterone formed prior to complete equilibration of $\mathrm{H}^{3}$-progesterone with the precursor pool or by synthesis of aldosterone via a pathway from progesterone which bypasses corticosterone (38).

\section{SUM M ARY}

Production of corticosteroids by adrenal slices from one patient with mild hypertension, one with malignant hypertension, and four with Cushing's syndrome was studied in vitro. The adrenal slices produced cortisol, cortisone, corticosterone, 11-deoxycortisól, and aldosterone; responded to ACTH stimulation; and incorporated radioactive precursors into biological compounds. Rates of production by the "normal," "hypertensive," "atrophic" and "Cushingoid" tissue expressed as micrograms per gram per 3 hours did not differ strikingly except for two adenomas which had reduced rates of production. However, because of their larger size, the total production per gland was greater for the hyperplastic and adenomatous tissue. The total production by the adrenals from 
the patient with malignant hypertension fell into the range of the latter groups. Incubation of adrenal glands obtained post mortem released no steroids into the media, despite the addition of cofactors.

The incorporation studies with progesterone$16-\mathrm{H}^{3}$ as the precursor suggest that a portion of cortisol is synthesized by a pathway which circumvents progesterone. The major pathway for aldosterone biosynthesis is through corticosterone, although an alternative pathway was not excluded.

\section{ACKNOWLEDGMENTS}

The authors wish to express their thanks to Mr. Albert Kuljian, Mr. Walter Herniak and Miss Patricia Tomassi for technical assistance; to Dr. Mark Hayes for his cooperation and interest; and to Dr. Philip K. Bondy for his advice and encouragement.

\section{REFERENCES}

1. Soffer, L. J., Eisenberg, J., Iannaccone, A., and Gabrilone, J. L. Cushing's syndrome in The Human Adrenal Cortex. Ciba Found. Coll. Endocr. 1955, 8, 487.

2. Symington, T., Currie, A. R., O'Donnell, V. J., Grant, J. K., Oastler, E. G., and Whyte, W. G. Hyperplasia and tumors of the human adrenal cortex: Histology, enzymic changes and corticoid production. Ciba Found. Coll. Endocr. 1958, 12, 102.

3. Karsner, H. T. Tumors of the Adrenal. Sect. VIII, Fasc. 29. Atlas of Tumor Pathology. Washington, D. C., Armed Forces Inst. of Pathology, 1950.

4. Heard, R. D. H., Bligh, E. G., Cann, M. C., Jellinck, P. H., O'Donnell, V. J., Rao, B. G., and Webb, J. L. Biogenesis of the sterols and the steroid hormones. Recent Progr. Hormone Res. 1956, 12, 45.

5. Lombardo, M. E., Hoitman, E., and Hudson, P. B. Conversion of progesterone, 17- $\alpha$-hydroxyprogesterone and 11-deoxycortisol to cortisol by the human adrenal gland in aitro. J. clin. Endocr. 1956, 16, 1283.

6. Grant, J. K., Symington, T., and Duguid, W. P. Effect of adrenocorticotropic therapy on the in vitro $11 \beta$-hydroxylation of desoxycorticosterone by human adrenal homogenates. J. clin. Endocr. 1957, 17, 933.

7. Berliner, M. L., Berliner, D. L., and Dougherty, T. F. Metabolism of progesterone by adrenal tissue from patients with Cushing's syndrome and mammary carcinoma. J. clin. Endocr. 1958, 18, 109.

8. Cooper, D. Y., Touchstone, J. C., Roberts, J. M., Blakemore, W. S., and Rosenthal, O. Steroid formation by adrenal tissue from hypertensives. J. clin. Invest. 1958, 37, 1524.
9. Bongiovanni, A. M. In vitro hydroxylation of steroids by whole adrenal homogenates of beef, normal man, and patients with the adrenogenital syndrome. J. clin. Invest. 1958, 37, 1342.

10. Bailey, R. E., Slade, C. I., Lieberman, A. H., and Luetscher, J. A., Jr. Steroid production by human adrenal adenomata and nontumorous adrenal tissue in vitro. J. clin. Endocr. 1960, 20, 457.

11. Dyrenfurth, I., Lucis, O. J., Beck, J. C., and Venning, E. H. Studies in patients with adrenocortical hyperfunction. III. In vitro secretion of steroids by human adrenal glands. J. clin. Endocr. 1960, 20, 765.

12. Saffran, M., and Bayliss, M. J. In vitro bioassay of corticotrophin. Endocrinology 1953, 52, 140.

13. Giroud, C. J. P., Stachenko, J., and Venning, E. H. Secretion of aldosterone by the zona glomerulosa of rat adrenal glands incubated in vitro. Proc. Soc. exp. Biol. (N. Y.) 1956, 92, 154.

14. Ayres, P. J., Gould, R. P., Simpson, S. A., and Tait, J. F. The in vitro demonstration of differential corticosteroid production within the ox adrenal gland (abstract). Biochem. J. 1956, 63, $19 \mathrm{P}$.

15. Burton, R. B., Zaffaroni, A., and Keutmann, E. H. Paper chromatography of steroids. II. Corticosteroids and related substances. J. biol. Chem. 1951, 188, 763.

16. Bush, I. E. Methods of paper chromatography of steroids applicable to study of steroids in mammalian bloods and tissues. Biochem. J. 1952, 50, 370.

17. Kliman, B., and Peterson, R. E. Double isotope derivative assay of aldosterone in biological extracts. J. biol. Chem. 1960, 235, 1639.

18. Abelson, D., and Bondy, P. K. Fluorometric determination of $\Delta^{4}$-3-ketosteroids. Arch. Biochem. 1955, 57, 208.

19. Mulrow, P. J. Unpublished observations.

20. Eberlein, W. R., and Bongiovanni, A. M. New solvent systems for the resolution of corticosteroids by paper chromatography. Arch. Biochem. 1955, 59, 90.

21. Romanoff, E. B., Hudson, P., and Pincus, G. Isolation of hydrocortisone and corticosterone from human adrenal vein blood. J. clin. Endocr. 1953, $13,1546$.

22. Touchstone, J. C., Cooper, D. Y., and Blakemore, IV. S. Identification of substance $S$ in human adrenal venous blood. J. clin. Endocr. 1959, 19, 812.

23. Moran, W. H., and Zimmermann, B. Aldosterone secretion measured during adrenal vein cannulation in humans. Program of Forty-second Meeting of Endocrine Soc., June, 1960, p. 15.

24. Neher, R. Aldosterone and other adrenocortical hormones in human adrenals and adrenal tumours in An International Symposium on Aldosterone, A. F. Muller and C. M. O'Connor, Eds. Boston Little, Brown, 1958, p. 11. 
25. Cope, C. L., and Black, E. The production rate of cortisol in man. Brit. med. J. 1958, 1, 1020.

26. Gelfman, N. A., Mulrow, P. J., and Yesner, R. A comparison of adrenocortical morphology and the clinical syndromes of autopsied patients. Clin. Res. 1960, 8, 240.

27. Doe, R. P., Vennes, J. A., and Flink, E. B. Diurnal variation of 17-hydroxycorticosteroids, sodium, potassium, magnesium and creatinine in normal subjects and in cases of treated adrenal insufficiency and Cushing's syndrome. J. clin. Endocr. 1960, 20, 266.

28. Laragh, J. H., Ulick, S., Januszewicz, V., Deming, Q. B., Kelly, W. G., and Lieberman, S. Aldosterone secretion and primary and malignant hypertension. J. clin. Invest. 1960, 39, 1091.

29. Genest, J., Koiw, E., Nowaczynski, W., and Sandor, T. Study of urinary adrenocortical hormones in human arterial hypertension. Advanced Abstracts of Short Communications, First International Congr. of Endocrinology, Copenhagen, July, 1960, p. 173.

30. Laragh, J. H., Angers, M., Kelly, W. G., and Lieberman, S. Hypotensive agents and pressor substances: The effect of epinephrine, norepinephrine, angiotensin II, and others on the secretory rate of aldosterone in man. J. Amer. med. Ass. 1960, 174, 234.

31. Davis, J. Proceedings of the Laurentian Hormone Conference, 1960.

32. Mulrow, P. J., and Ganong, W. F. Stimulation of aldosterone secretion by angiotensin II-A preliminary report. Yale J. Biol. Med. 1961, 33, 386.

33. Dorfman, R. I. Biosynthesis of steroids in hyperactive and tumour-bearing human glands. Ciba Found. Coll. Endocr. 1958, 12, 62.

34. Ayres, P. J., Garrod, O., Tait, S. A. S., and Tait, J. F. Primary aldosteronism (Conn's syndrome) in An International Symposium on Aldosterone, A. F. Muller and C. M. O'Connor, Eds. Boston, Little, Brown, 1958, p. 143.

35. Ross, E. J. Modification of the effects of aldosterone on electrolyte excretion in man by simultaneous administration of corticosterone and hydrocortisone. Relevance to Conn's syndrome. J. clin. Endocr. 1960, 20, 229.

36. Eichhorn, J., and Hechter, O. Status of deoxycorticosterone as intermediary in the biosynthesis of cortisol. Proc. Soc. exp. Biol. (N. Y.) 1957, 95, 311.

37. Eichhorn, J., and Hechter, O. The unequal incorporation of tracer progesterone- $\mathrm{C}^{14}$ into corticosterone and cortisol synthesized by homogenates of bovine adrenal cortex. Arch. Biochem. 1959, 84, 196.

38. Ayres, P. J., Eichhorn, J., Hechter, O., Saba, N., Tait, J. F., and Tait, S. A. S. Some studies on the biosynthesis of aldosterone and other adrenal steroids. Acta endocr. (Kbh.) 1960, 33, 27.

39. Weliky, J. Personal communication.

40. Vande Wiele, R., and Lieberman, S. The Metabolism of Dehydroandrosterone in Biological Activities of Steroids in Relation to Cancer. New York, Academic Press, 1960, p. 93.

41. Hechter, O., and Pincus, G. Genesis of adrenocortical secretion. Physiol. Rev. 1954, 34, 459.

42. Mulrow, P. J., and Cohn, G. L. Corticosteroid synthesis and release by human adrenal slices (abstract). J. clin. Invest. 1959, 38, 1028.

43. Kahnt, F. W., Neher, R., and Wettstein, A. Umwandlung von radioaktivem Cortexon in Aldosteron durch Nebennieren-Enzyme. Experientia (Basel) 1955, 11, 446.

44. Rosenberg, E., Rosenfeld, G., Ungar, R., and Dorfman, R. I. Conversion of steroids to aldosteronelike material. Endocrinology 1956, 58, 708.

45. Ayres, P. J., Hechter, O., Saba, N., Simpson, S. A. S., and Tait, J. F. Intermediates in the biosynthesis of aldosterone by capsule strippings of ox adrenal gland (abstract). Biochem. J. 1957, 65, 22P.

46. Travis, R. H., and Farrell, G. L. In vitro biosynthesis of isotopic aldosterone: Comparison of precursors. Endocrinology 1958, 63, 882.

47. Mulrow, P. J., and Cohn, G. L. Conversion of corticosterone-4- $\mathrm{C}^{14}$ to aldosterone by human adrenal slices. Proc. Soc. exp. Biol. (N. Y.) 1959, 101, 731. 